\title{
HOW MULTINATIONAL COMPANIES ENTRUST DIGITAL APPLICATIONS IN UPGRADING EMPLOYEES' HUMAN RESOURCES
}

Sri Mulyono

Institut Daarul Qur'an Jakarta, Indonesia

Email: srimulyono63@gmail.com

\begin{abstract}
Background: The problem of International Human Resources management is inseparable from cultural factors. Due to the cultural differences of each country, it is necessary to adjust the differences with modernization solutions and changing patterns of technological solutions.

The purpose of the study: Finally, we set the goal of this study to gain a new understanding of how and why international HR can be solved with digital applications

Research method: We have analyzed with the help of the Google translation application if there are difficulties in understanding terms and content, then examine the data and evaluation and conclude based on valid and reliable information accuracy. Because we found this data from the results of previous studies, we say our study is secondary data following experts' opinions. Then we also process this study as a qualitative and descriptive study.

The results of the study: digital technology can convince companies to train their HR; among others, companies can easily prepare their HR upgrades when they apply their digital technology applications. Furthermore, technology also has an essential role in implementing and corporate human resources training, including international companies. Digital has also been proven to be able to transform human resources for international companies. Our findings hope that they will become essential inputs and contributions for further studies and corporate policy issues

Conclusion: we come to our conclusion that the understanding that we get from the study of many papers published in well-known journals is that the purpose of our study has been obtained, which, among other things, we conclude that digital applications can increase the human resources of international companies because digital applications are indeed an essential element so that companies can easily believe in its superiority.

Keywords: Digital Applications, Upgrading Employees, Human Resources
\end{abstract}

Diterima: 25-12-2019 Direvisi: 5-01-2021 Disetujui: 6-01-2021

\section{INTRODUCTION}

More and more businesses are concentrating on the role of human resources as an essential component of their core competencies and a source of competitive advantage to compete effectively in the global marketplace (Porter, 2011). Human resources refer to the cumulative repository of each individual's knowledge, skills, and talents, which the business has developed over time into an identifiable set of skills (Rau and Adams, 2012). The challenge for multinational companies is maintaining and developing their human resources so that appropriately educated and globally oriented people can support strategic responses and contribute to core capabilities. More and more global companies are defining their own "universities" or "schools," demonstrating the importance of training and development of employees who operate training facilities assisted by effective and productive tools such as digital applications (Nda and Fard, 2013).

As we mentioned in the previous theme section, training and development programs are essential to implementing an international company's HR management system (Nivlouei, 2014). On the other hand, new employees often get some selection

\begin{tabular}{ll}
\hline & Sri Mulyono. (2021). How Multinational Companies Entrust Digital Applications In Upgrading \\
& Employees' Human Resources. Co-Value: Jurnal Ekonomi, Koperasi Kewirausahaan Vol \\
How to cite: & $12(1): 32-41$ \\
\hline E-ISSN: & https://greenpublisher.id/
\end{tabular}


training. Some may remember that each employee was given training at least five times before the store's operation, as is usually the case in small companies. However, this is not enough if a new HR wants to join a large company. For companies between nations, HR training and development is defined as strengthening and providing skills and competencies to carry out company duties. The training seeks to improve skills and behavior in the workplace, while development seeks to improve future employment, usually in managerial positions. We will start by looking at training methods and problems for each of the different types of workers. The influence of foreign assignments on career paths in multinational business and other development issues will be discussed, requiring upgrading tools and models with the help of digital technology for depth reasons (VARDARLIER, 2020).

The author believes that the study and search for understanding international human resource management are critical to be studied and communicated to many audiences because International Human Resources management uses international resources to achieve organizational goals regardless of geographic boundaries. Category of country or nation involved in International HRM activities: host country where a branch can be located. So on that basis, the author wants to get an understanding of why International HR is needed. After this study, of course, the core of the study will aim to ensure that multinational companies can continue to run and operate optimally in different countries by managing existing human resources and differing from HR in general. So, what global HR problems may arise in technology-based HR management or online evidence support.

The problem of International Human Resource Management remains an essential issue in the global era, and technology is ready to support it so that there is no reason for the business world to reject the presence of digital and internet-enabled equipment. (Nivlouei, 2014). We have to admit that the differences are quite a lot when international HR workers join as the culture of each country requires adjustment of differences. So this study will try to discuss it with the support of evidence from previous studies. For example, in the economic system, differences in regulatory systems also translate into differences in practice. We try to offer all of that with the help of technology and communication.

Legal and industrial factors are indeed a new problem, but with digital technology, they will quickly understand each other, and finally, any global HR problems that may arise in HR management can be resolved by themselves. The problem of International Human Resources management is inseparable from cultural factors. Due to the cultural differences of each country, it is necessary to adjust the differences with modernization solutions and changing patterns of technological solutions. Finally, we set the goal of this study to gain a new understanding of how and why international HR can be solved with digital applications. Parry and Strohmeier, (2014) where they believe that HRM in the digital era can well as bring challenges new changes.

\section{RESEARCH METHOD}

As we said at the beginning, we want to get input on why developing corporate human resources between nations can be done with the help of internet-based digital technology and applications was essential (Marler and Fisher, 2013). So then collected several international publications through internet search engines on high-impact publications such as Google Book, Wiley, Taylor \& France, Elsevier, and other databases. So, the data can answer our study questions. We have analyzed with the help of the Google translation application if there are difficulties in understanding terms and 
content, then examine the data and evaluation and conclude based on valid and reliable information accuracy. Because we found this data from the results of previous studies, we say our study is secondary data following experts' opinions. Then we also process this study as a qualitative and descriptive study (Parry and Strohmeier, 2014).

\section{RESULT AND DISCUSSION}

\section{Expatriate Education}

Most expatriates are well trained and selected from today's multinational business operations, with proven skills and employability. However, as shown in some instances, they remain an exception because they have the potential to be trained as they work (Briscoe et al., 2012). Given that technical competence is a crucial selection criterion, most of the literature must focus on expatriate training programs before departure, especially those focused on raising cultural awareness and understanding. When an employee is selected for an expatriate job, pre-departure training is an essential next step in ensuring the expatriate's effectiveness and success abroad, especially when country duties are considered culturally vital. Since many expatriates may know from discussions of expatriate failures, functional competence alone does not predict success, certain types of cultural preparation are recommended. Individuals who receive practical, cultural training adapt to new cultures more quickly. "The ultimate goal of intercultural training is to help individuals deal with unexpected events in the work culture between countries. (Helmreich and Merritt, 2017).

Expatriates only $25 \%$ of the 1,000 multinational companies in developed countries are provided with comprehensive pre-departure training sessions. Only $13 \%$ of respondents in 1989 said they would provide programs for expatriates (Cannavale and Claes, 2019). Another study shows that companies in many US countries use expatriate training programs less frequently than European and Japanese firms (32 percent compared to 69 percent). This condition does not make things a problem considering the current conditions are all digital where all employees can still update themselves with the help of technology (Chen and Chang, 2016). Even though such training is generally recognized, a significant percentage of US corporations do not provide it. European (especially Scandinavian) corporations have been shown to focus on pre-departure training, notably language training, then American multinationals.

HR strengthening also includes cultural awareness training, which is still the most common type of pre-departure training, according to a Price Waterhouse study of European businesses (including non-European multinational subsidiaries) conducted in 1997-98 (Cannavale and Claes, 2019). It is still given voluntarily rather than as a necessary necessity. Only $13 \%$ of businesses surveyed traditionally offer cultural awareness training to their expatriates, while another $47 \%$ are now prepared for a "difficult" culture (Alkire et al., 2014). Companies typically place less emphasis on offering pre-departure training for couples and families, regardless of country of origin. Multinational businesses are increasingly expanding their pre-departure training programs to include partners or spouses and children, perhaps due to increased awareness of the growing relationship between expatriate performance and family adjustment (HoweWalsh and Schyns, 2010).

\section{Program for Cultural Awareness}

It is widely recognized that to become successful workers; expatriates must adjust to their new environment and avoid feeling alienated from their home country (Wang and Tran, 2012). A well-designed cultural awareness training program may be of great help, 
as it aims to create an understanding of the host country's culture so that expatriates can act appropriately or imitate and shape acceptable behavior. Such training can also be taken with the help of digital technology (Fierbaugh, 2012). To illustrate this idea, Sieveking, Anchor, and Marston used Middle Eastern civilization. This is a place that values personal connection, trust, and respect in business dealings; Added to this is a solid religious focus that pervades almost every facet of life.

In such a scenario, the expatriate is likely to face some problems from the host country's culture; the expatriate will likely experience some difficulties during the international assignment (Okpara and Kabongo, 2011). Elements of cultural awareness programs vary by country of origin, length, transfer destination, and program provider. Abdullah and Jin, (2015) define five types of pre-departure training as part of their expatriate management research, based on various learning processes, types of work, assignments, and available time: Environmental and cultural orientation are two research areas of cultural program instruction.

Ko and Yang, (2011) suggest a contingency framework to assess the type and difficulty of expatriate training to understand potential variances better. The level of involvement required in the local culture and the similarity between local and foreign cultures are the two determining variables. Important training components of the framework include the substance of the training and the specificity of the training. If there is little anticipated contact between people and members of the local culture, and there is little difference between local and international cultures, training should concentrate on a task and work-related problems rather than cultural ones. The rigor needed for successful training should be kept to a minimum.

If the host country expects a high level of engagement and significant cultural differences, training should develop cross-cultural skills and new tasks (Lokkesmoe et al., 2016). Such instruction should have a moderate to a high degree of precision. Model Technological training sets the parameters for selecting a company's HR training method, including the anticipated interaction and cultural similarity level. One drawback is that it does not help determine which particular training technique to use or what constitutes a less or more intense exercise (Shepherd, 2019). The level of cross-cultural rigor must be high, and the training must be continued for two months if the person is to be acquainted with a new and different local culture with a high level of interaction. Training sensitivity, field experience, and culture between experiential workshops, in addition to the less rigorous techniques mentioned earlier, Therefore, it may be an appropriate training strategy in this scenario of digital technology training (Kaynak and Herbig, 2014).

According to Abbas et al., (2018) multinational companies currently do not question why multinational companies do not offer pre-departure training; it may not be challenging to design an effective pre-departure training program in such circumstances a real practical obstacle to the application of technology digital with a variety of applications that are suitable for the application. Contextual and situational variables are also important. Content, techniques, and procedures in cultural knowledge training programs can be influenced by cultural resilience, duration of assignment, and nature/type of work (Wilson et al., 2013). Monitoring and feedback, moreover, should be recognized as an essential component of individual capacity building. In particular, as a consequence of cultural knowledge training, as a result of adjustment and performance. So far, the solution is to return to trust in internet technology-based application tools (Leeflang et al., 2014). 
The understanding of the components of expatriate HR training above can be solved with digital technology. This highlights how important it is for prospective expatriates to pay attention to the behavior and outcomes of cultural awareness training programs and other job skills. Moreover, considering that application-based training sites can be easily accessed with no time and space limits, application replication fits the needs. According to our international workers' HR training management analysis, linking adjustment and performance to international performance management systems is very important. Poor performance, for example, can be improved by clarifying the technology's new incentives for more efficient innovation from the basic to the higher levels required or by providing additional cultural knowledge training. We examine the company's HR training management application system and performance-related achievements; Thite, (2018) treats adjustment and performance as distinct outcomes, with changes resulting in performance. We suggest that performance may affect adjustment when workers are given opportunities for innovation and technology adaptation in certain situations.

\section{Early worker}

Hiring foreign workers on their first trip as a host country is one method to direct them. (Wechtler, 2018). A well-planned vacation abroad for applicants and their spouses offers an overview to evaluate their suitability for the job. Before departure, a visit to the host site can aid early adjustment (Harris et al., 2016). A week is the average duration of the visit. The country of assignment of expatriates is a determining criterion; visits are not permitted if the expatriate is already acquainted with the country, perhaps through previous trips on corporate business or as a tourist, or if the country is considered culturally close Spouses may, understandably, decline assignments based on the first visit. "We do not offer first assignments when circumstances are terrible, and no one wants to quit," Price Waterhouse acknowledged in 1997-1998. Most businesses take advantage of yearly inspections, but they evaluate the dangers of premature recalls and underemployment. A possible issue that arises during the first visit is often part of the decision-making process.

\section{English as a Business Language}

Even though this type of English is more "international English" than native English speakers, English is not generally recognized as the world's business language (Zhang, 2013). This fact is often cited by multinational companies based in Englishspeaking countries, such as native speakers, as justification for not considering language proficiency in the recruitment process or prioritizing language training as part of a predeparture program. This attitude can lead to misunderstandings about the importance of foreign language skills. Being trained in a foreign language" was considered very important by $19 \%$ of US respondents than $64 \%$ of non-native respondents.

Aparicio Fenoll and Kuehn, (2016) conducted a study on European multinational foreign language requirements in the same year, finding that foreign language proficiency is rarely considered part of cross-cultural knowledge. Language difficulties are generally thought of as mechanical and controllable problems that can be overcome quickly. This is an easy problem to fix. Other speakers have power over what is communicated and understood. There is little room for maneuver for a single English speaker and no way for him to learn more than what is given to him (Fromm and Read, 2018). Her job forces her to be reactive rather than proactive in relationships. What he says and understands is filtered through the competence of other speakers, over which he has no control. Learning applications can help even though the workers have joined international workers. 
The lower the ethnocentrism workers perceive between nations, the more cultural awareness and language training will be provided (Shaw, 2020). Multinational companies in the US require US business schools to incorporate foreign languages into their curricula and prefer hiring graduates with foreign language skills. Language training is provided where it is needed for expatriates and spouses (81 percent) and children (42 percent). The constraints of English as the language of multiple nationalities companies can often be helped by advancing the world of online learning. Therefore, the best solution can also be entrusted to online learning applications (Riahi, 2015).

\section{Language and adaptation}

Being able to communicate in a foreign language improves an expatriate's effectiveness and bargaining abilities. Language skills have been recognized as a critical component of performance (Wang and Tran, 2012). The amount of time required to achieve even a basic level of competency may partially explain the continuing disregard of training after leaving. Linguistic multinationals' ability is harmed if they rely only on English. The lack of language proficiency hinders international businesses' capacity to watch rivals and analyze critical information. Fixman's statement on safeguarding vital technology in the joint venture's overseas activities was a truly solution (Cooke et al., 2019).

\section{Application for Business Communication}

More studies emphasize the potential effect of adopting a single corporate language on HRM operations in international companies. Communication skills in business practice are critical (Psychogios et al., 2016). Workers across nations may find themselves channeling communications between subsidiaries and headquarters. They may have access to information they would otherwise be denied if they were not proficient in the company language. This can also strengthen their status within the subsidiary. A predeparture training program can help ex-pats and their families by providing knowledge that helps in relocation. Many multinational companies are increasingly turning to relocation experts for help with practical matters (Ostrom et al., 2010).

Practical technology support is essential in assisting expatriates and their families in adjusting to their new environment. To ensure that practical support is provided, the company's HR team works closely with shipping line managers and HR departments in international locations. This solution can also come from various digital applications that are now getting hotter globally ( $\mathrm{Li}$ et al., 2017). Expats are often hired due to a shortage of suitably qualified personnel in the host site. As a consequence, expatriates are often forced to train HCNs in their place. The obvious issue is how foreigners are trained for training positions. A successful pre-departure training program may require covering certain work-related elements. When a multinational chooses to establish a manufacturing plant in a low-cost country, it quickly realizes that it will need to educate local workers significantly. HCN competency has significant training and cost implications, which may not be apparent at the time of national selection. There are many issues with HCN training, including a lack of emphasis on mode of operation.

Looking at solutions by companies in developed countries such as Japan, Nissin and Honda have successfully trained large numbers of human resources in their operations in many countries such as the USA, UK, and Europe (Collinson and Rugman, 2008). Some multinational companies are increasingly taking advantage of satellite technology to offer tailor-made training courses on-site from home to country to save money. This is especially true in technical training for operational personnel in areas where specific skills and work habits are strategic (Maslach and Leiter, 2008).

Workers can be relocated to the parent country and used as headquarters or a subsidiary operating at home. International employees are transferred for a variety of 
reasons: This allows for company-specific training. For example, the company Ericsson offers a two-level professional management program for its managers. The top 400 managers are served by 1,600 intermediary managers (Lee and Lee, 2009). Matsushita's annual import of 200 foreign managers to collaborate with their Japanese counterparts may be overkill. Inputs require a pre-departure training program comparable to expatriate placement in a recent paper. They recognize that technology is the most up-to-date solution, such as the application of strengthening skills and foreign languages (Miorandi et al., 2012).

\section{Multinational team}

One of the most well-known methods of creating multinational teams and international employees is international job rotation. The business offers external training programs such as the global leadership program at the University of Michigan (Stahl and Tung, 2015). International meetings held in different places also promote personal contacts and networks, forming global teams. According to the study, multinational companies will benefit from the inherent diversity to promote creativity, organizational learning, and knowledge transfer, consistent with the overall trend towards collaboration (Stahl and Tung, 2015). Everything that is done is inseparable from the program of optimizing high-tech human resources. Creating corporate brands and collaboration seems to be an essential element of global resources and ideas. In global business, the goal is to gather the best ideas from around the world. Ideas and experiences can collaborate through technology and face-to-face meetings. Each team contributes the best ideas and maintains a consistent approach. Corporate culture is built around it (Abdi et al., 2018). Those who help others by translating ideas from one location to another. They may win prizes, be praised, and be promoted. So, they solve every problem with a technological approach for smooth communication and collaboration (Shneiderman, 2016).

\section{CONCLUSION}

Therefore, we come to our conclusion that the understanding that we get from the study of many papers published in well-known journals is that the purpose of our study has been obtained, which, among other things, we conclude that digital applications can increase the human resources of international companies because digital applications are indeed an essential element so that companies can easily believe in its superiority. Other reasons, for example, digital technology can convince companies to train their HR; among others, companies can easily prepare their HR upgrades when they apply their digital technology applications. Furthermore, technology also has an essential role in implementing and corporate human resources training, including international companies. Digital has also been proven to be able to transform human resources for international companies. Our findings hope that they will become essential inputs and contributions for further studies and corporate policy issues.

\section{BIBLIOGRAPHY}

Abbas, M., Adil, M., Ehtisham-ul-Haque, S., Munir, B., Yameen, M., Ghaffar, A., Shar, G.A., Tahir, M.A., Iqbal, M., 2018. Vibrio fischeri bioluminescence inhibition assay for ecotoxicity assessment: a review. Sci. Total Environ. 626, 1295-1309.

Abdullah, D.N.M.A., Jin, C.S., 2015. Determining the types of training and development supports for expatriates. Procedia-Soc. Behav. Sci. 172, 548554. 
Alkire, S., Conconi, A., Seth, S., 2014. Multidimensional Poverty Index 2014: Brief methodological note and results.

Aparicio Fenoll, A., Kuehn, Z., 2016. Does foreign language proficiency foster migration of young individuals within the European Union. Econ. Lang. Policy 331-355.

Briscoe, D., Schuler, R., Tarique, I., 2012. International human resource management: Policies and practices for multinational enterprises. Routledge.

Cannavale, C., Claes, M.-T., 2019. Cultural values of self-initiated expatriates: a pilot study. Eur. J. Cross-Cult. Competence Manag. 5, 62-83.

Chen, H.-M., Chang, C.-C., 2016. Contingent expatriate training strategies with examples of Taiwan MNEs. J. Hum. Resour. Sustain. Stud. 4, 1.

Collinson, S., Rugman, A.M., 2008. The regional nature of Japanese multinational business. J. Int. Bus. Stud. 39, 215-230.

Cooke, F.L., Liu, M., Liu, L.A., Chen, C.C., 2019. Human resource management and industrial relations in multinational corporations in and from China: Challenges and new insights. Hum. Resour. Manage. 58, 455-471.

Fierbaugh, A.L., 2012. Prolonging the life of colleges on the edge: The impact of internal communication on employee satisfaction in small Christian colleges. Regent University.

Fromm, J., Read, A., 2018. Marketing to Gen Z: The rules for reaching this vastand very different-generation of influencers. Amacom.

Harris, P., Kent, J., Sainsbury, P., Thow, A.M., 2016. Framing health for land-use planning legislation: a qualitative descriptive content analysis. Soc. Sci. Med. 148, 42-51.

Helmreich, R.L., Merritt, A.C., 2017. Culture at work in aviation and medicine: National, organizational and professional influences. Routledge.

Howe-Walsh, L., Schyns, B., 2010. Self-initiated expatriation: implications for HRM. Int. J. Hum. Resour. Manag. 21, 260-273.

Kaynak, E., Herbig, P., 2014. Handbook of cross-cultural marketing. Routledge.

Ko, H.-C., Yang, M.-L., 2011. The effects of cross-cultural training on expatriate assignments. Intercult. Commun. Stud. 20.

Lee, G., Lee, C.-K., 2009. Cross-cultural comparison of the image of Guam perceived by Korean and Japanese leisure travelers: Importanceperformance analysis. Tour. Manag. 30, 922-931.

Leeflang, P.S., Verhoef, P.C., Dahlström, P., Freundt, T., 2014. Challenges and solutions for marketing in a digital era. Eur. Manag. J. 32, 1-12. 
Li, G., Hou, Y., Wu, A., 2017. Fourth Industrial Revolution: technological drivers, impacts and coping methods. Chin. Geogr. Sci. 27, 626-637.

Lokkesmoe, K.J., Kuchinke, K.P., Ardichvili, A., 2016. Developing cross-cultural awareness through foreign immersion programs: Implications of university study abroad research for global competency development. Eur. J. Train. Dev.

Marler, J.H., Fisher, S.L., 2013. An evidence-based review of e-HRM and strategic human resource management. Hum. Resour. Manag. Rev. 23, 1836.

Maslach, C., Leiter, M.P., 2008. The truth about burnout: How organizations cause personal stress and what to do about it. John Wiley \& Sons.

Miorandi, D., Sicari, S., De Pellegrini, F., Chlamtac, I., 2012. Internet of things: Vision, applications and research challenges. Ad Hoc Netw. 10, 14971516.

Nda, M.M., Fard, R.Y., 2013. The impact of employee training and development on employee productivity. Glob. J. Commer. Manag. Perspect. 2, 91-93.

Nivlouei, F.B., 2014. Electronic human resource management system: The main element in capacitating globalization paradigm. Int. J. Bus. Soc. Sci. 5.

Okpara, J.O., Kabongo, J.D., 2011. Cross-cultural training and expatriate adjustment: A study of western expatriates in Nigeria. J. World Bus. 46, $22-30$.

Ostrom, A.L., Bitner, M.J., Brown, S.W., Burkhard, K.A., Goul, M., SmithDaniels, V., Demirkan, H., Rabinovich, E., 2010. Moving forward and making a difference: research priorities for the science of service. J. Serv. Res. 13, 4-36.

Parry, E., Strohmeier, S., 2014. HRM in the digital age-digital changes and challenges of the HR profession. Empl. Relat.

Porter, M.E., 2011. Competitive advantage of nations: creating and sustaining superior performance. simon and schuster.

Psychogios, A., Szamosi, L.T., Prouska, R., Brewster, C., 2016. A three-fold framework for understanding HRM practices in South-Eastern European SMEs. Empl. Relat.

Rau, B.L., Adams, G.A., 2012. Aging, Retirement, and Human Resources Management: A Strategic. Oxf. Handb. Retire. 117.

Riahi, G., 2015. E-learning systems based on cloud computing: A review. Procedia Comput. Sci. 62, 352-359.

Shaw, H., 2020. Sticking Points: How to Get 5 Generations Working Together in the 12 Places They Come Apart. Tyndale House Publishers, Inc. 
Shepherd, S.M., 2019. Cultural awareness workshops: limitations and practical consequences. BMC Med. Educ. 19, 1-10.

Shneiderman, B., 2016. The New ABCs of Research: Achieving Breakthrough Collaborations. Oxford University Press.

Stahl, G.K., Tung, R.L., 2015. Towards a more balanced treatment of culture in international business studies: The need for positive cross-cultural scholarship. J. Int. Bus. Stud. 46, 391-414.

Thite, M., 2018. e-HRM: digital approaches, directions \& applications. Routledge.

VARDARLIER, P., 2020. Digital transformation of human resource management: digital applications and strategic tools in HRM, in: Digital Business Strategies in Blockchain Ecosystems. Springer, pp. 239-264.

Wang, Y.-L., Tran, E., 2012. Effects of cross-cultural and language training on expatriates' adjustment and job performance in V ietnam. Asia Pac. J. Hum. Resour. 50, 327-350.

Wechtler, H., 2018. "Life if elsewhere": A diary study of female self-initiated expatriates' motivations to work abroad. Career Dev. Int.

Wilson, J., Ward, C., Fischer, R., 2013. Beyond culture learning theory: What can personality tell us about cultural competence? J. Cross-Cult. Psychol. 44, 900-927.

Zhang, Z., 2013. Business English students learning to write for international business: What do international business practitioners have to say about their texts? Engl. Specif. Purp. 32, 144-156.

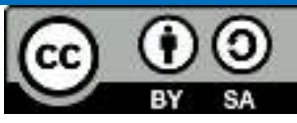

This work is licensed under a Creative Commons Attribution-ShareAlike 4.0 International License 